\title{
User Attitude and Intentions Towards FinTech in Bangladesh
}

\author{
Fairtown Zhou Ayoungman, Yunus Social Enterprise Center, Business School, Zhengzhou University, China \\ Nazmul Hasan Chowdhury, Yunus Social Enterprise Center, Business School, Zhengzhou University, China \\ Nida Hussain, Yunus Social Enterprise Center, Business School, Zhengzhou University, China \\ Papel Tanchangya, Yunus Social Enterprise Center, Business School, Zhengzhou University, China
}

\begin{abstract}
FinTech is considered a need for modern financial methods to compete with traditional financial methods. The combination of innovation, technology, and finance develops a unique method that could be a source of economic development in developing countries. Modern technologies are essential to recognize the user attitude, behaviour, and intentions towards FinTech. Hence, the key objective of the study is to investigate the user attitude and intentions towards the adoption of FinTech in Bangladesh. Under the light of the technology acceptance model and theory of planned behaviour, the following study used perceived trust, perceived usefulness, perceived compatibility, perceived cost efficiency, and perceived risk as independent variables towards attitudes and intentions of the users towards FinTech products. The study collected data from 450 FinTech users from Bangladesh, and the proposed relationship among variables were measured by structural equation model by using SMART-PLS. The research findings will benefit FinTech operators to create more customized services for local consumers.
\end{abstract}

\section{KEYWORDS}

Customer Acceptance, Digital Bangladesh, Finance and Technology, FinTech, Technology Acceptance Model, Technology Development

\section{INTRODUCTION}

Financial technology (FinTech) is a unique combination of technology and finance, that drawn under the innovative strategies and provide solutions to facilitate day-to-day emerging financial problem (Berg et al., 2020). FinTech has delivered an incredible rise in the global marketplace, particularly in India, China and the UK. Alipay, E-wallet, crypto-currency, Paypal, peer-to-peer (P2P) borrowing, corporate sponsorship, and InsureTech are peer operators in the international market (Anagnostopoulos, 2018). In a niche market, some FinTech service providers are keener to provide extraordinary user services and products to enhance users technology experiences. Mobile operators and the banking industry have now become the key FinTech service and product providers that offer popular items to individuals and corporate businesses (Bömer \& Maxin, 2018). While FinTech is still very much in infancy in the Asian market (Eickhoff et al., 2017), numerous studies have been directed, which not only examine the benefits and costs of FinTech but also provide the latest solutions for individual and business sectors (Juengerkes, 2016). 
In recent years, investors are more interested to invest in FinTech. Big data, crypto-currency (Jonker, 2019), mobile networks (Wu \& Wang, 2005), cloud computing (sH. Amin, 2009) and banking (Manrai \& Manrai, 2007) were highly trendy towards the advancement in financial development and innovation in the market. The digital transformation of mobile banking is somehow dependable on investment in information and communication technology.

Under the Bangladeshi context, the following research is related to the overall knowledge and adoption of FinTech products among local consumers or users. They are generally inadequate to access FinTech services. Therefore, to analyze the engagement and understanding of FinTech by Bangladeshi customers, a conceptual model has been proposed. Furthermore, the objective of the research study is to establish the conceptual elements that may stimulate the knowledge and acceptance among the target consumers of FinTech services and products. Moreover, consumer behaviour toward the acceptance of FinTech services and products is discussed. In recognizing and encouraging the use of FinTech products and services, the results would be beneficial to researchers, FinTech operators and businesses. The outcome of this research is expected to be a breakthrough that would make a foremost contribution to Bangladesh's economy in its digitalization process.

This study implemented the Technology Acceptance Model (TAM) and Theory of Planned Behaviour (TPB) to understand the user acceptance intentions towards Fintech services and product. This study analyzes the dynamics that affect users intention to use FinTech services and products in Bangladesh. the following research is developed to expand the TAM model, which resulted in 5 additional determinants to assess the attitude and consumers intentions for using FinTech services and products. The determinants are Perceived Trust (PT), Perceived Usefulness (PU), Perceived Compatibility (PCOM), Perceived Cost Efficiency (PCE) and Perceived Risk (PR).

The following research paper is structured as follows. In the following section, significant literature is studied, and a developed conceptual model and some theory are acquainting in detail. Under the light of TAM and TBP hypothesis of study has been developed. Thus, data analysis and results have been discussed in the discussion section. In last, the study concludes with limitations and proposed suggestions for future research work.

\section{LITERATURE REVIEW}

In the modern era, technology is the basic pillar of any developed and developing economy. Countries are working hard to deliver their best to provide technological access to each individual. Due to this competition, many new innovative solutions have been observed globally (Stern et al., 2017). Now technology is not limited only to information systems but is revolutionizing all sectors of the economy. Hence, the financial revolution under the technology spectrum is now being observed globally (Schmidt et al., 2018).

\section{Financial Technology (FinTech)}

Researchers focused to study the association of technological development with the financial revolution under diverse perceptions of FinTech. Subsequently, McKinnon and Shaw in 1973 first time proposed the "Financial Deepening" terminology that developed sci-tech promptly in the global market (Hermes $\&$ Lensink, 2008). The combination of finance and technology has brought a disruptive change in the financial market (Omarini, 2018). It has opened the doors for new entries to start their business in the competitive market. Fintech mentioned as a set of new tools with updated techniques to use information technology inappropriate ways such as blockchain, big data, cloud computing, digital financing and the Internet of Things (IoT) platforms (Nakashima, 2018). Gai et al. (2018) defined "Fintech as a financial technology section is one important element in any company that would improve service quality and management efficiency by using a new generation of information technology". Consequently, the advancement of FinTech to improve technology is indeed driving the perpetual development in investment sector (Milian et al., 2019). The classified FinTech systems assume the role of financial technology in a broader domain that enhances operating conditions for companies 
or organizations. Moreover, their main target is to improve delivery services of FinTech efficiently to users (Omarini, 2018)

Recently, FinTech services reached beyond digital banking or e-banking financial services (Yin $\&$ Gai, 2015). Currently, FinTech service providers are more focused on the consumer perspective that increase the utilization of the monetary service industry and familiarize them with innovative technology. RBI financial report reported that FinTech services have inclusive market growth that possibly increases the effectiveness and lessen the risk (Viswanathan, 2014). This transition has therefore entered into a new developmental phase with the parameters being the effects on developed nations, that are now comparable to those for emerging economies (Sudiatmika \& Purwanti, 2020). It is observed that various aspects of FinTech affect economic and financial operation in developed and developing countries (Anagnostopoulos, 2018).

Significant innovations made in various fields, such as wireless networks, data analytics, user authentication, integrated mobile devices, data storage, image recognition, and strategies for data analytics (H. Kim \& Shin, 2017) have contributed to a wide variety of FinTech systems in different domains. Due to a variety of driving forces, including technology growth, research and innovation expectations (market), cost-saving criteria, and consumer demands, FinTech has become a hot topic in the market. Moreover, the financial technology-based sector is looking for support for the improvement of individual funding requirements and industry organizations to improve their business performance in the market (Hornuf et al., 2020). Therefore, FinTech has been deemed amongst the most significant investments for many successful financial institutions.

\section{FinTech in Bangladesh}

FinTech is the modern age of digitization. Furthermore, it is transforming the financial business paradigm. Many nations have permitted all specifications of FinTech to be implemented in their country, while others have their concerns. Although each nation is distinctive in its natural environment since they have distinct laws and regulations premised on the needs of the country. Throughout the scenario of Bangladesh, a couple of FinTech operators are temporarily authorized to perform their tasks. Moreover, few operators are systematically related to global access but rarely applicable domestically. Currently, 28 licenses are issued to operators for mobile financing by the government of Bangladesh. The key components of Fintech in Bangladesh are shown in Table 1.

\section{Concept of Digital Bangladesh}

The "Digital Bangladesh" ideology involves ensuring the democracy and rights of people, openness, integrity, maintaining justice and facilitating the provision of government programs at each doorstep by full use of technology, with the ultimate aim of improving the lifestyle of common Bangladeshi (M. S. Islam \& Grönlund, 2011). In "Digital Bangladesh" government covers all groups of citizens and does not differentiate in terms of innovation against individuals (A. Islam \& Tsuji, 2011). Keeping this in mind, the Bangladeshi government has outlined the four components of the "Digital Bangladesh" Vision (Figure 1), which seem to be the creation of human capital, the participation of citizens, state administration including the use of information technologies in the workplace (WHO, 2020). One of the key aspects of "Digital Bangladesh" is to update financial related issues (Zaman, 2015). Ministry of ICT recently worked hard to launch different programs related to FinTech.

More than 5600 digital centres have been installed in various government sectors. These centres currently provide services to 465 million users, and the government is working to update the extension to the 6 million remaining users (Ullah, 2020). Moreover, thousands of local entrepreneurs earn revenues above 41 million US dollars by using technology centres (Siddik \& Rahi, 2020). In the ICT sector, IT-related industries generate revenue of 1 billion US dollars. In 2018-2019, numerous tech-oriented companies exported their products and services to 36 countries around the globe. In addition to all this, the government is focusing on establishing 28 Tech Parks all over the country. 
Table 1. Components of FinTech in Bangladesh (Source: Author)

\begin{tabular}{|c|c|c|}
\hline Components & Status & Discussion \\
\hline $\begin{array}{l}\text { Crowd-Funding } \\
\text { Crowd-Lending } \\
\text { Fund Raising } \\
\text { Activities }\end{array}$ & $\begin{array}{l}\text { - (Limited Access) } \\
\text { - Inflow-Permitted } \\
\text { - Policing Making } \\
\text { Process } \\
\text { - Outflow } \\
\text { - Restricted }\end{array}$ & $\begin{array}{l}\text { - Under the act of "The Foreign Exchange Regulation Act, } 1947 \text { and } \\
\text { Money Laundering Prevention Act, 2012"(B. Parliament, 2012). } \\
\text { - The outflow of any transfer is strictly restricted. } \\
\text { - Inflows are permitted by law under the policy. }\end{array}$ \\
\hline $\begin{array}{l}\text { Crypto-Currency } \\
\text { Block-Chain }\end{array}$ & - (Illegal by Law) & $\begin{array}{l}\text { - Bitcoin and Crypto-currency are strictly controlled by the following } \\
\text { legal law of Bangladesh. } \\
\text { - The Foreign Exchange Regulation Act, } 1947 \\
\text { - Money Laundering Prevention Act,2012 } \\
\text { - Information and Communication Technology Act, 2006. (Law, } \\
\text { 1947; B. Parliament, 2012; B. N. Parliament, 2006) }\end{array}$ \\
\hline $\begin{array}{l}\text { Internet Banking } \\
\text { Internet-only Banking } \\
\text { Mobile Banking } \\
\text { Digital Banking }\end{array}$ & $\begin{array}{l}\text { - Mobile Banking } \\
\text { - Licensed with } \\
\text { several regulations. } \\
\text { - Internet-only } \\
\text { Banking is } \\
\text { - Circumscribed. } \\
\text { - Digital Banking } \\
\text { - Allowed. }\end{array}$ & $\begin{array}{l}\text { - Bangladesh Bank authorizes mobile banking (MB) for domestic } \\
\text { payment services for cash in and out, person to the government (PG), } \\
\text { person to business (PB), person to person (PP), business to person } \\
\text { (BP), and government to person (GP). } \\
\text { - Under this operation, no cross-border transfer of money is permitted. } \\
\text { However, local reimbursement through the financial intermediary of } \\
\text { inward foreign remittance is allowed. } \\
\text { - Banks can be run even without bank store on the Internet only } \\
\text { baking process. However, in Bangladesh, no banks are licensed to } \\
\text { function without even a physical branch. Consequently, Neo banking } \\
\text { is necessarily limited. } \\
\text { - Digital banking is authorized, such as payment cards and some } \\
\text { mobile wallets. }\end{array}$ \\
\hline Insurance Tech & (Not Allowed) & $\begin{array}{l}\text { - A digital framework or crypto-currency is not authorized to file } \\
\text { insurance under section } 23 \text { of the Bangladesh Insurance Act } 2010 \\
\text { (Law, 2010) }\end{array}$ \\
\hline
\end{tabular}

The idea of "Digital Bangladesh" shows that technology distributions should reach every end-user in society (Zaman, 2015). Technology's availability is not limited to ICT but also reaches down to each individual, and will also give access to advanced technologies such as cloud computing in every sector across the country (Alam et al., 2020; Aziz, 2020). A study conducted shows that an overarching

Figure 1. Source from Information Access from Prime Minister Office Bangladesh (WHO, 2020)

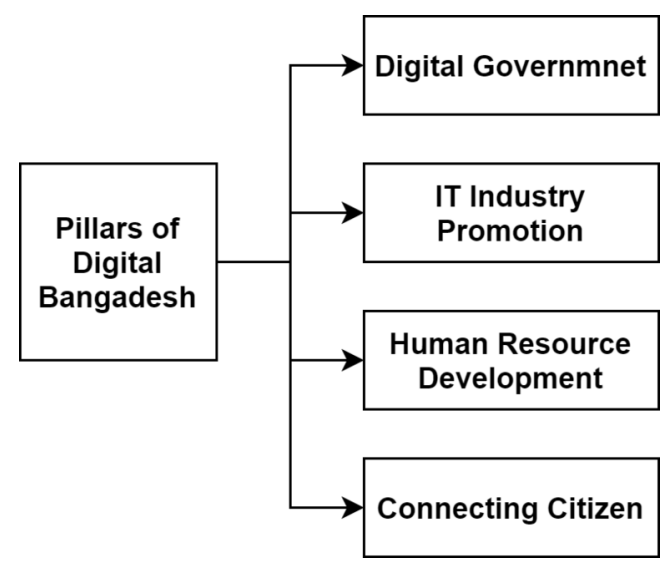


theme of how ICT can bring about improvements in the key areas of "Digital Bangladesh" (Mazumdar \& Alharahsheh). Although the government is trying to adopt different strategies to digitalize the nation, it is still a dream from the current perspective of the "Digital Bangladesh" idea (S. B. Amin \& Rahman, 2019). By 2021, the country could be digitally advanced, if the government operates this plan honestly and explicitly implements at different ICT programs under strong leadership with a proper roadmap (Hoque, 2020).

\section{THEORETICAL AND CONCEPTUAL FRAMEWORK}

\section{Technology Acceptance Model (TAM)}

TAM has initially recommended to addresses the deficiencies of the Theory of Reasoned Action (TRA) in 1986. The Technology Acceptance Model (TAM) was formulated by Davis in 1986 (Azajna, 1996). The main concept behind the proposal was to understand the ground reality of behavioural science, self-efficacy theory and integrating expectation theory. Moreover, the main objective of the study was to apprehend user behavioural intentions towards technology usage (Davis, 1989). Therefore, Ghazizadeh et al. (2012) state that this model aims to predict the public acceptance of a tool and techniques and to recognize the improvements that must be introduced to the system. This model indicates that two key factors evaluate the appropriateness of information technology and infrastructure solutions (Holden \& Karsh, 2010). Moreover, it identifies the user behavioural attitudes into perceived usefulness and perceived ease of use, which holds a significant influence on the technology adoption (Park et al., 2014). TAM has been effectively employed in several diverse sectors including agriculture, psychology, education, communication, and information systems (Szajna, 1996). TAM has committed its primary growth to recognize the adoption of information technology or innovation by consumers. In computer system and technology implementation, TAM is an extremely probabilistic classifier (Surendran, 2012).

The conceptual perspective of TAM is therefore to understand FinTech's unique features that are capable of recognizing and forecasting the adoption of a new system or innovation (McCloskey, 2004). TAM is a simple model that gives insights for appreciating user participation and provides user-friendly technology with effective knowledge. Under the TAM, the adoption of IT services and products by users are measured by effort expectancy, effectiveness and a comfortable user-friendly environment (Marangunić \& Granić, 2015). Hence, a person's level of confidence will boost job efficiency using a particular method (Berg et al., 2020; KRISTOF-BROWN, 2000).

According to TAM, the expectation about using any technology is ascendant by Perceived Usefulness (PU) and Perceived Ease of Use (PEU) that is the notch of an individual level of trust for system acceptance will be free of extra effort. TAM stressed that information quality directly affects the behavioural intention of the consumer while perceived ease of use indirectly influences the behavioural intention by performance expectancy. A 107-user longitudinal study to assess their plan to use this framework was conducted by Legris et al. (2003), their study suggested that ease of use is incredibly important, although a more crucial factor is for the model to be useful. The resulting model from their analysis is therefore classified as systematic TAM.

\section{Theory of Planned Behaviour (TPB)}

The Theory of Planned Behavior is an adaptation of the concept for deliberate action made by a relevant entity, that identifies the weaknesses of the existing model in addressing activities over which an individual has incomplete volitional influence (Ajzen, 1985, 1991).

Attitudes reflect personal views about positive and negative measures of behavioural success. Somehow, the person will observe the performance change in the behaviour (Ajzen \& Driver, 1991; Brayley et al., 2015). In addition, assumptions about the impending results of actions are thought to evaluate attitudes towards behaviour (Ajzen, 1991; Beck \& Ajzen, 1991). 
Figure 2. Conceptual Framework

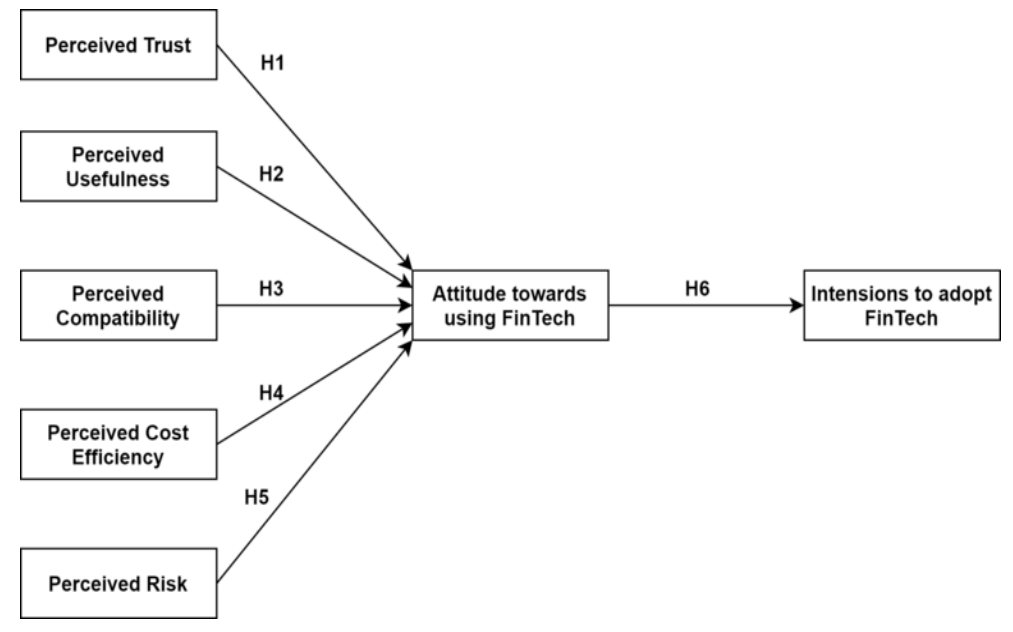

Subjective Norms (SN) influence the social impact of an individual's behavioural background (an example being the conduct of an individual that his/her peers and community are expected to praise) (Conner \& Armitage, 1998). As such, it is believed that normative standards are influenced by assumptions about the attitudes and actions of those concerning the behaviour (Shi et al., 2017).

The Perceived Behavioral Control (PBC) represents the perceived ability of an individual to conduct actions. This might include accessibility of the skills and necessary resources for behavioural performance (e.g., the degree to which distinct has the capacity, an interval of time, equipment, etc.) needed to achieve a given behaviour (Godin \& Kok, 1996). It has been recognized that perceived behavioural regulation functions as both a pre-intention (consuming an indirect link with actions by targets) and an instantaneous precedent for behaviour (having a clear connotation with performance) (Z. Chen et al., 2017; Orbell et al., 1997). That is, for some activities, PBC can be partially or entirely regulated by intended governing bodies (Conner \& Armitage, 1998).

\section{Conceptual Framework}

Keeping the ideology of TAM and TPB, the following conceptual model has been developed for this research (Figure 2). With technology and human intention, FinTech can bring a change in the financial market (M. A. Chen et al., 2019).

\section{Hypothesis Development}

\section{Perceived Trust (PT)}

Perceived Trust (PT) is distinct as "The degree of effect on consumer trust toward enterprises that provide Fintech Service by brand and system security" (Gefen et al., 2003; Paul, 2003; J. Singh \& Sirdeshmukh, 2000). Likewise, the products and services of FinTech are important to make it easier for future consumers to trust emerging technologies to be embraced. PT can have a huge effect on the consumer's perspective towards the adoption of FinTech. Trust is one of the main factors due to its high dimensional information elaborating its usage in the products and services. Consequently, study on trust is considered excessively important to analyze an emotional impact on the attitudes of users and their inclination to assume (M. K. O. Lee \& Turban, 2001; McKnight \& Chervany, 2001). Roy et al. (2012) revealed that PT can encourage user behaviours, and shaped products and services into their integral features for future needs. This study considers that trust mentions users as an inclusive attribute to believe in FinTech services and products. Hanafizadeh et al. (2014) investigated some 
indication about indirect effects of trust on the adoption of Fintech services or products. In other words, more trust in service or product, more willingness of users to use that service or product (Basak et al., 2016; Koksal, 2016). Keeping the above discussion in mind following hypothesis has been established:

Hypothesis One: $\left(\mathrm{H}_{1}\right)$ Perceived Trust $(P T)$ has a significant positive impact on user attitude using FinTech.

\section{Perceived Usefulness (PU)}

Davis (1989) stated that PU is the user understanding level with the system and technology that directly and indirectly impact their performance by using a particular system. Previous studies identify the positive influence of user consumer's attitude especially method of using the particular system and technology (M. K. O. Lee \& Turban, 2001; Lim \& Cham, 2015; Venkatesh \& Davis, 2000). Such consequence may highlight the user attentions towards FinTech services and products that are user-friendly. A Taiwanese based study by Chuang et al. (2016), investigates that PU was diligently connected with the customer's attitude towards the usage of FinTech services and products. Besides, Al-Fahim et al. (2016) study demonstrated about the banking sector in Yemen, that PU impact positively on banking method, this helps to indicate how many consumers showing positive response towards intentions and attitude to actively participate in internet banking. Briefly understanding the above all arguments, this research hypothesized that:

Hypothesis Two: $\left(\mathrm{H}_{2}\right)$ Perceived Usefulness $(P U)$ has a significant positive impact on user attitude using FinTech.

\section{Perceived Compatibility (PCOM)}

Researchers defined PCOM as the amount of reliability about a product or service by users, with the fact that technology is reliable or compatible for a user to maintain their needs, wants and values (Mallat, 2007; Oliveira et al., 2016). C. Kim et al. (2010) examined aspects that directly affect PU and user intentions. This study exposed that PCOM and innovation are key elements of PU and perceived ease of use. (Kuo \& Yen, 2009) definite that PCOM is an antecedent of PU and impact the user intentions. N. Singh and Sinha (2020) discussed the Indian user intentions, that PCOM impact on the systems and positively impact on the behaviour intentions. However, up to some extent, PCOM affects user attitude remains undefined under the context of FinTech services and products. In consequence, this research hypothesized that:

Hypothesis Three: $\left(\mathrm{H}_{3}\right)$ Perceived Compatibility (PCOMP) has a significant positive impact on user attitude using FinTech.

\section{Perceived Cost Efficiency (PCE)}

Perceived Cost Efficiency (PCE) stated that the acceptable level that allows a consumer to considers his willpower to incur the cost for using a service and product (Kleijnen Wetzels et al., 2004). In monetary terms user willingness to invest money in a specific technology. Kleijnen Wetzels and de Ruyter (2004) discussed that cost has a negative consequence on user attitude towards the usage of technology. Additionally, Luarn and Lin (2005) reported about PCE, negatively impact user behaviour. According to this study, cost is the main factor of user attitude, specifically when purchasing services 
and products. Likewise, Kuo and Yen (2009), shows in their work that cost also negatively influence the information technology setting, users become more concerned about the value-added services by companies. On the other hand, Wu and Wang (2005) stated that the mobile market is very apprehension about cost, according to them potentially users effected with cost decisons towards the system practice. Nevertheless, up to what magnitude the PCE of spending on FinTech's products and services will impact users' attitude and intention will be remains indeterminate. Therefore, based on the facts above, hypothesis has been formulated:

Hypothesis Four: $\left(\mathrm{H}_{4}\right)$ Perceived Cost Efficiency (PCE) has a significant positive impact on user attitude using FinTech.

\section{Perceived Risk (PR)}

Cox and Rich (1964) mentioned the uncertain behaviour or experiences that affect individuals and users in decision making. Hence, PR is referred to as uncertain individual behaviour towards the decision-making process. With information and technology evolution, the organization and users are more concerned about security risk. Therefore, PR could be assumed as a safety risk or confidentiality threat in which individual specific and individual information data could be stolen (Amaro \& Duarte, 2015; Cham et al., 2016; Cham et al., 2018; Cox \& Rich, 1964; Yiu et al., 2007). M.-C. Lee (2009) studied the negative impact of PR on a person's attitude to the usage of specific technical services and products. Precisely, the greater the PR, the smaller amount satisfies the user attitude towards the specific technological service and product. M.-C. Lee (2009), identify that "security risk has a significant impact on users' attitude and is an important factor toward adoption of technology products". Martins et al. (2014) described internet banking, that PR has a huge impact on customer's attitude towards payments. Their attitude influences positively and negatively on the user intentions to use such services and products. The customer's expectations of the ambiguity and adversative effects of purchasing services and products are viewed as a risk. The potential risk is a willingness to embrace when situations trigger uncertainty and frustration. Based on the above discussed evidences, it is determined that PR will help to understand the user attitude towards FinTech's services and products. Therefore, following hypothesis has been developed:

Hypothesis Five: $\left(\mathrm{H}_{5}\right)$ Perceived Risk $(P R)$ has a significant positive impact on user attitude using FinTech.

\section{Linking Attitude and Intention to FinTech}

The previous literature determines that attitude plays a significantly linking part in the user behavioural intentions (Hsu \& Lin, 2016; Venkatesh \& Davis, 2000). Thus, if the personal experience is good about Fintech usage for services and products, their willingness will increase to use the same service and products next time. Later in Chuang Liu and Kao (2016) support the evidence that user attitude and behaviours in Taiwan have a positive impact. Likewise, the study determines the usage of Mobile Enterprise Applications (MEA) as a positive influence on user behaviour and intentions. Furthermore, $\mathrm{Gu}$ et al. (2009) expounded that attitude is certainly significant to a customer's intent to practice online or e-banking. Therefore, the above evidence recognized that attitude to technology usage was meticulously related. With that, the succeeding hypothesis has been developed:

Hypothesis Six: $\left(\mathrm{H}_{6}\right)$ Users' Attitude (UA) has a significant positive impact on the intention to adopt Fintech. 


\section{METHODOLOGY}

\section{Data Collection}

This study focused on the FinTech products and services associated with mobile banking (those use mobiles for payments or money transfer). First of all, the study identified the already available measuring scales in the existing research literature. The study used a five-point Likert scale to measure the mean of each question. Thus, 1 indicates "Strongly Disagree" while 5 indicate the "Strongly Agree" in statements. Secondly, data was collected from the user of mobile banking in Bangladesh. 600 questionnaires were distributed among the mobile user and local customer to better understand the intentions towards FinTech products and services in Bangladesh. However, 450 questionnaires were received fully completed.

\section{Measuring Scale}

Chong et al. (2010) measuring scale was used to identify the items for PT. The item of the scale was "I believe Fintech services keep my personal information safe". Huh et al. (2009) and Lockett and Littler (1997) measuring scale was adopted for PU. The item of the scale was "Overall, Fintech services are useful to me". Perceived Compatibility (PCOMP) measuring scaled adopted from Bradford and Hayashi (2014), items states as "FinTech is compatible and appropriate to my work". PCE used Bradford and Hayashi (2014) and Hu et al. (1999). Its items were "FinTech products or services installations cost is not very high". Marakarkandy et al. (2017) measuring scale was adopted for PR. Item of the scale was "I believe that the money is easy to be stolen by using Fintech services". For measuring the User Attitude (UA) study used Grabner-Kräuter and Faullant (2008) used scale items. Item of the scale includes "Using FinTech services is a pleasant experience." Marakarkandy Yajnik and Dasgupta (2017) measuring scale was used for User Intensions (UI). Item of the scale includes "I would like to use Fintech services soon".

\section{Data Analysis}

The following study used PLS path modelling also known as partial least square path modelling. The reason for adopting the PLS path modelling method is because PLS path modelling is widely implemented by management, social science or other related disciplines researchers for better understanding (Hair et al., 2012; Rouf \& Akhtaruddin, 2018). Hence the study of PLS path modelling is a favourable analytical procedure to predict the dependent variable (Hair et al., 2012). Therefore, PLS path modelling is used to measure the variance-based structural equation modelling (SEM) techniques (Sarstedt \& Cheah, 2019). Consequently, the study employed SEM using SmartPLS 3 software.

\section{Measuring Model}

The measuring model helps to evaluate the individual item reliability, internal consistency reliability and composite reliability (CR), convergent validity and discriminant validity. For individual item reliability, the value should be above 0.5 (Hulland, 1999). F. Hair Jr et al. (2014) stated a rule of thumb for holding the items between 0.40 and 0.70 are sufficient to fulfil the reliability criteria. Hence the outer loadings should be greater or equal to 0.5 (Hair et al., 2014). Therefore, the present study effectively fulfils the criteria of outer individual loading (Table 3).

According to Bagozzi and Yi (1988) and (Hair et al., 2012) composite reliability should be interpreted above 0.7 or above. They also suggest that 0.747 to 0.880 ranges are good for internal consistency reliability. Some researchers also argue that a fair threshold may be anywhere between 60 and up (Dao et al., 2020). Table 4 identifies the CR of the present study that satisfies the demanded 
Table 2: Descriptive statistics of Bangladeshi Users

\begin{tabular}{|c|c|c|c|}
\hline & Demographic Details & Frequencies & Percentage $(\%)$ \\
\hline \multirow[t]{2}{*}{ Gender } & Male & 289 & 66 \\
\hline & Female & 146 & 34 \\
\hline \multirow[t]{4}{*}{ Age } & $20-30$ & 148 & 33 \\
\hline & $31-40$ & 180 & 40 \\
\hline & $41-50$ & 89 & 20 \\
\hline & Above 50 & 33 & 7 \\
\hline \multirow[t]{5}{*}{ Education } & Higher School Level & 26 & 6 \\
\hline & College Level & 85 & 19 \\
\hline & Undergraduate level & 125 & 28 \\
\hline & Graduate-level & 190 & 42 \\
\hline & others & 24 & 5 \\
\hline \multirow[t]{5}{*}{ Job Status } & Business Owner & 208 & 46 \\
\hline & Government Employee & 66 & 15 \\
\hline & Student & 50 & 11 \\
\hline & Workers & 80 & 18 \\
\hline & Other & 46 & 10 \\
\hline \multirow{3}{*}{$\begin{array}{c}\text { Mobile Operate use } \\
\text { for money transfer or } \\
\text { payments }\end{array}$} & Bkash under BRAC. & 302 & 67 \\
\hline & $\begin{array}{l}\text { Rocket under DBBL (Dutch Bangla } \\
\text { Bank Limited). }\end{array}$ & 107 & 24 \\
\hline & Others & 41 & 9 \\
\hline
\end{tabular}

range of internal consistency. Smaller-scale item numbers tend to result in lower levels of reliability, whereas larger-scale item numbers tend to have higher levels (Crump et al., 2020).

The value of Convergent Validity is supposed to be 0.50 (Bagozzi \& Yi, 1988). Average Variance Extractions (AVE) is suggested by Fornell and Larcker (1981). The AVE of the following study is mention in a table which is 0.5 and above, hence it fulfils the AVE criteria scores according to Sarstedt et al. (2014).

Discriminant validity mentions the correlation among each variable. It is considered good if there is no correlation among each variable and they measured different from each other. In Table 4 the values of Discriminant validity is good.

\section{Structural Model}

After executing the measuring model, this study used Structural Model (SM) to test the hypothesis. According to Peng and Lai (2012), if $\mathrm{t}>1.96$, with the $\mathrm{p}<0.05, \mathrm{t}>2.58$, with $\mathrm{p}<0.01$ and $\mathrm{t}>3.1$, with $\mathrm{p}<0.001$ are supposed to supporting hypothesis. Hence, Table 5 shows;

For assessing the coefficient of determination (R-square), one or more independent variables can explain the variation in the dependent proposition independent variable (F. Hair Jr et al., 2014; Hair et al., 2012; Ringle et al., 2015). Hair et al. (2012) agrees that the value of $\mathrm{R}^{2}$ is acceptable at a different level, particularly under which context research is conducted.

If $R^{2}$ is 0.10 is usually acceptable by Shiau et al. (2019). However, Chin et al. (2003) proposed that if $\mathrm{R}^{2}$ is 0.60 can be considered good, 0.33 is considered and modest value of $R^{2}$ and 0.19 a weak 
Table 3. Standardized Factor Loadings; AVE and CR

\begin{tabular}{|c|c|c|c|c|}
\hline Construct & Items & Standard Estimated Loadings & AVE & CR \\
\hline \multirow{5}{*}{ Perceived Trust } & PT1 & 0.767 & \multirow{5}{*}{0.65} & \multirow{5}{*}{0.903} \\
\hline & PT2 & 0.823 & & \\
\hline & PT3 & 0.841 & & \\
\hline & PT4 & 0.798 & & \\
\hline & PT5 & 0.798 & & \\
\hline \multirow{5}{*}{ Perceived Usefulness } & PU1 & 0.853 & \multirow{5}{*}{0.66} & \multirow{5}{*}{0.886} \\
\hline & PU2 & 0.747 & & \\
\hline & PU3 & 0.784 & & \\
\hline & PU4 & 0.861 & & \\
\hline & PU5 & 0.861 & & \\
\hline \multirow{3}{*}{ Perceived Compatibility } & PCOM1 & 0.753 & \multirow{3}{*}{0.588} & \multirow{3}{*}{0.811} \\
\hline & PCOM2 & 0.785 & & \\
\hline & PCOM3 & 0.762 & & \\
\hline \multirow{5}{*}{ Perceived Cost Efficiency } & PCE1 & 0.757 & \multirow{5}{*}{0.552} & \multirow{5}{*}{0.86} \\
\hline & PCE2 & 0.78 & & \\
\hline & PCE3 & 0.739 & & \\
\hline & PCE4 & 0.72 & & \\
\hline & PCE5 & 0.716 & & \\
\hline \multirow{3}{*}{ Perceived Risk } & PR1 & 0.722 & \multirow{3}{*}{0.708} & \multirow{3}{*}{0.878} \\
\hline & PR2 & 0.907 & & \\
\hline & PR3 & 0.883 & & \\
\hline \multirow{4}{*}{ User Attitude } & UA1 & 0.816 & \multirow{4}{*}{0.667} & \multirow{4}{*}{0.889} \\
\hline & UA2 & 0.852 & & \\
\hline & UA3 & 0.838 & & \\
\hline & UA4 & 0.756 & & \\
\hline \multirow{4}{*}{ User Intention } & UI1 & 0.929 & \multirow{4}{*}{0.703} & \multirow{4}{*}{0.903} \\
\hline & UI2 & 0.709 & & \\
\hline & UI3 & 0.764 & & \\
\hline & UI4 & 0.929 & & \\
\hline
\end{tabular}

value of $\mathrm{R}^{2}$. The Present study obtained a value of $\mathrm{R}^{2}$ for UA was 0.43 and UI was 0.56 . Hence, there was a 56\% variance observed in UI. According to Chin Marcolin and Newsted (2003), the obtained $R^{2}$ value of the present study is greater than 0.33 and less than 0.60 which shows that the $R^{2}$ value is modest.

\section{DISCUSSION}

Due to the interconnected world, dynamic interconnected structures, and characteristic demands, a significantly expanded perception of using FinTech has caused a major challenge in its adoption and 
Table 4. Discriminant validity of constructs

\begin{tabular}{|l|r|r|r|r|r|r|r|}
\hline Constructs & \multicolumn{1}{l|}{ PCE } & \multicolumn{1}{l|}{ PCOM } & \multicolumn{1}{l|}{ PR } & \multicolumn{1}{l|}{ PT } & \multicolumn{1}{l|}{ PU } & UA & \multicolumn{1}{l|}{ UI } \\
\hline PCE & 0.743 & & & & & & \\
\hline PCOM & 0.371 & 0.767 & & & & & \\
\hline PR & 0.409 & 0.354 & 0.841 & & & & \\
\hline PT & 0.408 & 0.238 & 0.308 & 0.806 & & & \\
\hline PU & 0.48 & 0.364 & 0.319 & 0.284 & 0.813 & & \\
\hline UA & 0.395 & 0.246 & 0.282 & 0.859 & 0.285 & 0.817 & \\
\hline UI & 0.508 & 0.377 & 0.306 & 0.319 & 0.858 & 0.342 & 0.839 \\
\hline
\end{tabular}

Table 5. Structural Model $(\mathrm{P}<0.05)$

\begin{tabular}{|l|l|l|l|l|l|}
\hline \multicolumn{1}{|c|}{ Hypothesis Relationship } & Beta & \multicolumn{1}{c|}{$\begin{array}{c}\text { Standard } \\
\text { Deviation }\end{array}$} & T-Testing & P-Value & Result \\
\hline $\begin{array}{l}\mathrm{H}_{1}: \text { Perceived Trust (PT) has a significant positive } \\
\text { impact on user attitude using FinTech. }\end{array}$ & 0.4331 & 0.331 & 3.167 & 0.000 & Supporting \\
\hline $\begin{array}{l}\mathrm{H}_{2}: \text { Perceived Usefulness (PU) has a significant } \\
\text { positive impact on user attitude using FinTech. }\end{array}$ & 0.2011 & 0.324 & 2.907 & 0.000 & Supporting \\
\hline $\begin{array}{l}\mathrm{H}_{3}: \text { Perceived Compatibility (PCOM) has a } \\
\text { significant positive impact on user attitude using } \\
\text { FinTech. }\end{array}$ & 0.2846 & 0.431 & 2.913 & 0.002 & Supporting \\
\hline $\begin{array}{l}\mathrm{H}_{4}: \text { Perceived Cost Efficiency (PCE) has a } \\
\text { significant positive impact on user attitude using } \\
\text { FinTech. }\end{array}$ & 0.3748 & 0.327 & 2.156 & 0.035 & Supporting \\
\hline $\begin{array}{l}\mathrm{H}_{5}: \text { Perceived Risk (PR) has a significant positive } \\
\text { impact on user attitude using FinTech. }\end{array}$ & 0.0641 & 0.231 & 3.184 & 0.003 & Supporting \\
\hline $\begin{array}{l}\mathrm{H}_{6}: \text { Users' Attitude (UA) has a significant positive } \\
\text { impact on the intention to adopt Fintech. }\end{array}$ & 0.3421 & 0.522 & 6.784 & 0.000 & Supporting \\
\hline
\end{tabular}

planning. This research seeks to examine and extract the obvious concepts and sources mentioned in the FinTech industry, especially under the context of Bangladeshi users.

Consistent with $\mathrm{H}_{1}$ and $\mathrm{H}_{2}$ results support the hypothesis and suggest that PT and PU play a vital role in FinTech Adoption in Bangladesh. According to Sikdar and Makkad (2015), study results PU, PT and UI have a positive impact on the user intentions towards Fintech services or products adoption. Furthermore, $\mathrm{H}_{3}$ and $\mathrm{H}_{4}$ are also supported. KHANAM (2020) discussed cost-saving and helping poor people adopting FinTech. This study discussed the scenario of Bangladesh Cost Efficiency holds a strong impact on user behaviour.

Thus, $\mathrm{H}_{5}$ and $\mathrm{H}_{6}$ are supported in the study. Kleijnen de Ruyter et al. (2004), studies identifies that PR and PCOM is key factors of FinTech adoption. It is impossible to avoid PCOM from consumer adoption of technology. Roy Kesharwani and Bisht (2012) study results provide evidence about the negative impact of PR on FinTech services or products adoption.

These results are comparable to the previous studies. Certainly, scholars considered that user intention and attitude have a usually strong impact on the adoption of technology, services or products. This study reveals that Bangladeshi users are still in the early stage of adoption of FinTech products and services. 


\section{CONCLUSION}

This research determines the acceptance of FinTech in Bangladesh. The attitude of the local users is highly positive towards the FinTech services and products. Results show that perceived cost and perceived trust holds a strong effect on the consumer. PA holds a strong influence on FinTech users to adopt the sector's services and products. They stated that if FinTech companies provide easy accessibility to them they will prefer to start using these services and products. Therefore, a positive attitude has been observed towards mobile banking. The user also tries to highlight the importance of PCOM and PCE, which holds a significant influence on their behaviour. With better policies implementation and cost-effective strategies, mobile operators can help new customers to adopt FinTech in daily life. The main objective of this research was based on the conceptual factors presented under the shadow of TAM and TPB. Hence, all assumed hypothesis support the empirical study.

This study doesn't discuss government policies in detail. Digital Bangladesh is initiated program by the government. However, future researches need to identify Government initiation as a construct of study. 


\section{REFERENCES}

Ajzen, I. (1991). The theory of planned behavior. Organizational Behavior and Human Decision Processes, 50(2), 179-211. doi:10.1016/0749-5978(91)90020-T

Ajzen, I., \& Driver, B. L. (1991). Prediction of leisure participation from behavioral, normative, and control beliefs: An application of the theory of planned behavior. Leisure Sciences, 13(3), 185-204. doi:10.1080/01490409109513137

Al-Fahim, N. H., Jusoh, W. J. W., \& Abideen, A. (2016). An examination factors influencing the intention to adopt internet banking among SMEs in Yemen: Using an extension of the technology acceptance model (TAM). Journal of Internet Banking and Commerce.

Alam, M. Z., Hu, W., \& Uddin, A. (2020). Digital transformation in healthcare services sector of bangladesh: Current status, challenges and future direction. Journal on Innovation and Sustainability RISUS, 11(1), 30-38. doi:10.23925/2179-3565.2020v11i1p30-38

Amaro, S., \& Duarte, P. (2015). An integrative model of consumers' intentions to purchase travel online. Tourism Management, 46, 64-79. doi:10.1016/j.tourman.2014.06.006

Amin, H. (2009). An analysis of online banking usage intentions: An extension of the technology acceptance model. International Journal of Business and Society, 10(1), 27.

Amin, S. B., \& Rahman, S. (2019). The role of ICT in energy sector: towards a Digital Bangladesh by 2021. In Energy Resources in Bangladesh. Springer.

Anagnostopoulos, I. (2018). Fintech and regtech: Impact on regulators and banks. Journal of Economics and Business, 100, 7-25. doi:10.1016/j.jeconbus.2018.07.003

Aziz, A. (2020). Digital inclusion challenges in Bangladesh: The case of the National ICT Policy. Contemporary South Asia, 28(3), 304-319. doi:10.1080/09584935.2020.1793912

Bagozzi, R. P., \& Yi, Y. (1988). On the evaluation of structural equation models. Journal of the Academy of Marketing Science, 16(1), 74-94. doi:10.1007/BF02723327

Basak, S. K., Govender, D. W., \& Govender, I. (2016). Examining the impact of privacy, Security, and trust on the TAM and TTF models for e-commerce consumers: A pilot study. Paper presented at the 2016 14th Annual Conference on Privacy, Security and Trust (PST).

Beck, L., \& Ajzen, I. (1991). Predicting dishonest actions using the theory of planned behavior. Journal of Research in Personality, 25(3), 285-301. doi:10.1016/0092-6566(91)90021-H

Berg, T., Burg, V., Gombović, A., \& Puri, M. (2020). On the rise of fintechs: Credit scoring using digital footprints. Review of Financial Studies, 33(7), 2845-2897. doi:10.1093/rfs/hhz099

Bido, D., da Silva, D., \& Ringle, C. (2014). Structural Equation Modeling with the Smartpls. Brazilian Journal of Marketing, 13(2).

Bömer, M., \& Maxin, H. (2018). Why fintechs cooperate with banks-evidence from germany. Zeitschrift für die gesamte Versicherungswissenschaft, 107(4), 359-386. 10.1007/s12297-018-0421-6

Bradford, T., \& Hayashi, F. (2014). Mobile payments: Merchants' perspectives. Economic Review, 33-58.

Brayley, N., Obst, P. L., White, K. M., Lewis, I. M., Warburton, J., \& Spencer, N. M. (2015). Examining the predictive value of combining the theory of planned behaviour and the volunteer functions inventory. Australian Journal of Psychology, 67(3), 149-156. doi:10.1111/ajpy.12078

Cham, T. H., Lim, Y. M., Cheng, B. L., \& Lee, T. H. (2016). Determinants of knowledge management systems success in the banking industry. VINE Journal of Information and Knowledge Management Systems, 46(1), 2-20. doi:10.1108/VJIKMS-03-2014-0021

Cham, T. H., Ng, C. K. Y., Lim, Y. M., \& Cheng, B. L. (2018). Factors influencing clothing interest and purchase intention: A study of Generation Y consumers in Malaysia. International Review of Retail, Distribution and Consumer Research, 28(2), 174-189. doi:10.1080/09593969.2017.1397045 
Chen, M. A., Wu, Q., \& Yang, B. (2019). How Valuable Is FinTech Innovation? Review of Financial Studies, 32(5), 2062-2106. doi:10.1093/rfs/hhy130

Chen, Z., Li, Y., Wu, Y., \& Luo, J. (2017). The transition from traditional banking to mobile internet finance: An organizational innovation perspective - a comparative study of Citibank and ICBC. Financial Innovation, 3(1), 12. doi:10.1186/s40854-017-0062-0

Chin, W. W., Marcolin, B. L., \& Newsted, P. R. (2003). A partial least squares latent variable modeling approach for measuring interaction effects: Results from a Monte Carlo simulation study and an electronic-mail emotion/ adoption study. Information Systems Research, 14(2), 189-217. doi:10.1287/isre.14.2.189.16018

Chong, A., Ooi, K., Lin, B., \& Tan, B. (2010). Online banking adoption: An empirical analysis. International Journal of Bank Marketing, 28(4), 267-287. doi:10.1108/02652321011054963

Chuang, L.-M., Liu, C.-C., \& Kao, H.-K. (2016). The adoption of fintech service: TAM perspective. International Journal of Management and Administrative Sciences, 3(7), 1-15.

Conner, M., \& Armitage, C. J. (1998). Extending the Theory of Planned Behavior: A Review and Avenues for Further Research. Journal of Applied Social Psychology, 28(15), 1429-1464. doi:10.1111/j.1559-1816.1998. tb01685.x

Cox, D. F., \& Rich, S. U. (1964). Perceived Risk and Consumer Decision-Making-The Case of Telephone Shopping. JMR, Journal of Marketing Research, 1(4), 32-39. doi:10.1177/002224376400100405

Crump, R. T., Peterson, A., Charbonneau, C., Carlson, K. V., Sutherland, J. M., \& Baverstock, R. J. (2020). Evaluating the measurement properties of the 26-item Expanded Prostate Cancer Index Composite (EPIC-26) with a multicenter cohort. Canadian Urological Association Journal, 14(4), 111. PMID:31702548

Dao, D. A., Kim, D., Park, J., \& Kim, T. (2020). Precipitation threshold for urban flood warning-an analysis using the satellite-based flooded area and radar-gauge composite rainfall data. Journal of Hydro-environment Research, 32, 48-61. doi:10.1016/j.jher.2020.08.001

Davis, F. D. (1989). Perceived usefulness, perceived ease of use, and user acceptance of information technology. Management Information Systems Quarterly, 13(3), 319-340. doi:10.2307/249008

Eickhoff, M., Muntermann, J., \& Weinrich, T. (2017). What do FinTechs actually do? A taxonomy of FinTech business models. Academic Press.

McCloskey, D. (2004). Evaluating Electronic Commerce Acceptance with the Technology Acceptance Model. Journal of Computer Information Systems, 44(2), 49-57. doi:10.1080/08874417.2004.11647566

Fornell, C., \& Larcker, D. F. (1981). Structural Equation Models with Unobservable Variables and Measurement Error: Algebra and Statistics. JMR, Journal of Marketing Research, 18(3), 382-388. doi:10.1177/002224378101800313

Gai, K., Qiu, M., \& Sun, X. (2018). A survey on FinTech. Journal of Network and Computer Applications, 103, 262-273. doi:10.1016/j.jnca.2017.10.011

Gefen, D., Karahanna, E., \& Straub, D. W. (2003). Inexperience and experience with online stores: The importance of TAM and trust. IEEE Transactions on Engineering Management, 50(3), 307-321. doi:10.1109/ TEM.2003.817277

Ghazizadeh, M., Lee, J. D., \& Boyle, L. N. (2012). Extending the Technology Acceptance Model to assess automation. Cognition Technology and Work, 14(1), 39-49. doi:10.1007/s10111-011-0194-3

Godin, G., \& Kok, G. (1996). The Theory of Planned Behavior: A Review of its Applications to HealthRelated Behaviors. American Journal of Health Promotion, 11(2), 87-98. doi:10.4278/0890-1171-11.2.87 PMID:10163601

Grabner-Kräuter, S., \& Faullant, R. (2008). Consumer acceptance of internet banking: The influence of internet trust. International Journal of Bank Marketing, 26(7), 483-504. doi:10.1108/02652320810913855

Gu, J.-C., Lee, S.-C., \& Suh, Y.-H. (2009). Determinants of behavioral intention to mobile banking. Expert Systems with Applications, 36(9), 11605-11616. doi:10.1016/j.eswa.2009.03.024 
Hair, Jr, Sarstedt, Hopkins, \& Kuppelwieser. (2014). Partial least squares structural equation modeling (PLSSEM). European Business Review, 26(2), 106-121. doi:10.1108/EBR-10-2013-0128

Hair, J. F., Sarstedt, M., Pieper, T. M., \& Ringle, C. M. (2012). The Use of Partial Least Squares Structural Equation Modeling in Strategic Management Research: A Review of Past Practices and Recommendations for Future Applications. Long Range Planning, 45(5), 320-340. doi:10.1016/j.1rp.2012.09.008

Hanafizadeh, P., Behboudi, M., Abedini Koshksaray, A., \& Jalilvand Shirkhani Tabar, M. (2014). Mobile-banking adoption by Iranian bank clients. Telematics and Informatics, 31(1), 62-78. doi:10.1016/j.tele.2012.11.001

Hermes, N., \& Lensink, R. (2008). Does financial liberalization influence saving, investment and economic growth? Evidence from 25 emerging market economies, 1973-96. In Financial development, institutions, growth and poverty reduction. Springer.

Hoque, S. M. S. (2020). Government Information and Service Delivery Through Union Digital Centers in Bangladesh: Users' Perceptions on Good Governance. International Journal of Electronic Government Research, 16(3), 45-64. doi:10.4018/IJEGR.2020070103

Hornuf, L., Klus, M. F., Lohwasser, T. S., \& Schwienbacher, A. (2020). How do banks interact with fintech startups? Small Business Economics, 1-22. doi:10.1007/s11187-020-00359-3

Hsu, C.-L., \& Lin, J. C.-C. (2016). Effect of perceived value and social influences on mobile app stickiness and in-app purchase intention. Technological Forecasting and Social Change, 108, 42-53. doi:10.1016/j. techfore.2016.04.012

Hu, P. J., Chau, P. Y. K., Sheng, O. R. L., \& Tam, K. Y. (1999). Examining the Technology Acceptance Model Using Physician Acceptance of Telemedicine Technology. Journal of Management Information Systems, 16(2), 91-112. doi:10.1080/07421222.1999.11518247

Huh, H. J., Kim, T., \& Law, R. (2009). A comparison of competing theoretical models for understanding acceptance behavior of information systems in upscale hotels. International Journal of Hospitality Management, 28(1), 121-134. doi:10.1016/j.ijhm.2008.06.004

Hulland, J. (1999). Use of partial least squares (PLS) in strategic management research: A review of four recent studies. Strategic Management Journal, 20(2), 195-204. doi:10.1002/(SICI)1097-0266(199902)20:2<195::AID$\mathrm{SMJ} 13>3.0 . \mathrm{CO} ; 2-7$

Islam, A., \& Tsuji, K. (2011). Bridging digital divide in Bangladesh: Study on community information centers. The Electronic Library, 29(4), 506-522. Advance online publication. doi:10.1108/02640471111156768

Islam, M. S., \& Grönlund, ̊. (2011). Digital Bangladesh-a change we can believe in? Paper presented at the International Conference on Electronic Government and the Information Systems Perspective. doi:10.1007/9783-642-22961-9_9

Jonker, N. (2019). What drives the adoption of crypto-payments by online retailers? Electronic Commerce Research and Applications, 35, 100848. doi:10.1016/j.elerap.2019.100848

Juengerkes, B. E. (2016). FinTechs and Banks-Collaboration is Key. The FinTech book: The financial technology handbook for investors, entrepreneurs and visionaries, 179-182. 10.1002/9781119218906.ch47

Khanam, M. J. J. (2020). Regulatory Challenges and Social Opportunities of Financial Inclusion through FinTech in Developing Countries with Reference to Bangladesh. Academic Press.

Kim, C., Mirusmonov, M., \& Lee, I. (2010). An empirical examination of factors influencing the intention to use mobile payment. Computers in Human Behavior, 26(3), 310-322. doi:10.1016/j.chb.2009.10.013

Kim, H., \& Shin, D.-H. (2017). The effects of platform as a technology standard on platform-based repurchases. Digital Policy. Regulation \& Governance, 19(2), 153-167. Advance online publication. doi:10.1108/DPRG11-2016-0054

Kleijnen, M., de Ruyter, K., \& Wetzels, M. (2004). Consumer adoption of wireless services: Discovering the rules, while playing the game. Journal of Interactive Marketing, 18(2), 51-61. doi:10.1002/dir.20002

Kleijnen, M., Wetzels, M., \& de Ruyter, K. (2004). Consumer acceptance of wireless finance. Journal of Financial Services Marketing, 8(3), 206-217. doi:10.1057/palgrave.fsm.4770120 
Koksal, M. H. (2016). The intentions of Lebanese consumers to adopt mobile banking. International Journal of Bank Marketing, 34(3), 327-346. doi:10.1108/IJBM-03-2015-0025

Kristof-Brown, A. L. (2000). Perceived applicant fit: Distinguishing between recruiters' perceptions of person-job and person-organization fit. Personnel Psychology, 53(3), 643-671. doi:10.1111/j.1744-6570.2000.tb00217.x

Kuo, Y.-F., \& Yen, S.-N. (2009). Towards an understanding of the behavioral intention to use 3G mobile valueadded services. Computers in Human Behavior, 25(1), 103-110. doi:10.1016/j.chb.2008.07.007

Law, B. (1947). The Foreign Exchange Regulation Act, 1947.

Law, B. (2010). Bangladesh Insurance Act.

Lee, M.-C. (2009). Factors influencing the adoption of internet banking: An integration of TAM and TPB with perceived risk and perceived benefit. Electronic Commerce Research and Applications, 8(3), 130-141. doi:10.1016/j.elerap.2008.11.006

Lee, M. K. O., \& Turban, E. (2001). A Trust Model for Consumer Internet Shopping. International Journal of Electronic Commerce, 6(1), 75-91. doi:10.1080/10864415.2001.11044227

Legris, P., Ingham, J., \& Collerette, P. (2003). Why do people use information technology? A critical review of the technology acceptance model. Information \& Management, 40(3), 191-204. doi:10.1016/S0378-7206(01)00143-4

Lim, Y. M., \& Cham, T. H. (2015). A profile of the Internet shoppers: Evidence from nine countries. Telematics and Informatics, 32(2), 344-354. doi:10.1016/j.tele.2014.10.002

Lockett, A., \& Littler, D. (1997). The adoption of direct banking services. Journal of Marketing Management, 13(8), 791-811. doi:10.1080/0267257X.1997.9964512

Luarn, P., \& Lin, H.-H. (2005). Toward an understanding of the behavioral intention to use mobile banking. Computers in Human Behavior, 21(6), 873-891. doi:10.1016/j.chb.2004.03.003

Mallat, N. (2007). Exploring consumer adoption of mobile payments - A qualitative study. The Journal of Strategic Information Systems, 16(4), 413-432. doi:10.1016/j.jsis.2007.08.001

Manrai, L. A., \& Manrai, A. K. (2007). A field study of customers' switching behavior for bank services. Journal of Retailing and Consumer Services, 14(3), 208-215. doi:10.1016/j.jretconser.2006.09.005

Marakarkandy, B., Yajnik, N., \& Dasgupta, C. (2017). Enabling internet banking adoption: An empirical examination with an augmented technology acceptance model (TAM). Journal of Enterprise Information Management, 30(2), 263-294. doi:10.1108/JEIM-10-2015-0094

Marangunić, N., \& Granić, A. (2015). Technology acceptance model: A literature review from 1986 to 2013. Universal Access in the Information Society, 14(1), 81-95. doi:10.1007/s10209-014-0348-1

Martins, C., Oliveira, T., \& Popovič, A. (2014). Understanding the Internet banking adoption: A unified / theory of acceptance and use of technology and perceived risk application. International Journal of Information Management, 34(1), 1-13. doi:10.1016/j.jinfomgt.2013.06.002

McKnight, D. H., \& Chervany, N. L. (2001). What trust means in e-commerce customer relationships: An interdisciplinary conceptual typology. International Journal of Electronic Commerce, 6(2), 35-59. doi:10.108 0/10864415.2001.11044235

Milian, E. Z., Spinola, M. M., \& de Carvalho, M. M. (2019). Fintechs: A literature review and research agenda. Electronic Commerce Research and Applications, 34, 100833. doi:10.1016/j.elerap.2019.100833

Nakashima, T. (2018). Creating credit by making use of mobility with FinTech and IoT. IATSS Research, 42(2), 61-66. doi:10.1016/j.iatssr.2018.06.001

Oliveira, T., Thomas, M., Baptista, G., \& Campos, F. (2016). Mobile payment: Understanding the determinants of customer adoption and intention to recommend the technology. Computers in Human Behavior, 61, 404-414. doi:10.1016/j.chb.2016.03.030

Omarini, A. E. (2018). The retail bank of tomorrow: a platform for interactions and financial services. Conceptual and managerial challenges. 10.22158/rem.v3n2p110 
Orbell, S., Hodgkins, S., \& Sheeran, P. (1997). Implementation Intentions and the Theory of Planned Behavior. Personality and Social Psychology Bulletin, 23(9), 945-954. doi:10.1177/0146167297239004 PMID:29506445

Park, N., Rhoads, M., Hou, J., \& Lee, K. M. (2014). Understanding the acceptance of teleconferencing systems among employees: An extension of the technology acceptance model. Computers in Human Behavior, 39, 118-127. doi:10.1016/j.chb.2014.05.048

Parliament, B. (2012). Money Laundering Prevention Act, 2012.

Parliament, B. N. (2006). Bangladesh: Information and Communication Technology Act draconian 2006.

Paul, A. P. (2003). Consumer Acceptance of Electronic Commerce: Integrating Trust and Risk with the Technology Acceptance Model. International Journal of Electronic Commerce, 7(3), 101-134. doi:10.1080/1 0864415.2003.11044275

Peng, D. X., \& Lai, F. (2012). Using partial least squares in operations management research: A practical guideline and summary of past research. Journal of Operations Management, 30(6), 467-480. doi:10.1016/j. jom.2012.06.002

Rouf, M. A., \& Akhtaruddin, M. (2018). Factors affecting the voluntary disclosure: A study by using smart PLS-SEM approach. International Journal of Law and Management, 60(6), 1498-1508. doi:10.1108/ IJLMA-01-2018-0011

Roy, S. K., Kesharwani, A., \& Bisht, S. S. (2012). The impact of trust and perceived risk on internet banking adoption in India. International Journal of Bank Marketing, 30(4), 303-322. Advance online publication. doi:10.1108/02652321211236923

Sarstedt, M., \& Cheah, J.-H. (2019). Partial least squares structural equation modeling using SmartPLS: A software review. Journal of Marketing Analytics, 7(3), 196-202. doi:10.1057/s41270-019-00058-3

Sarstedt, M., Ringle, C. M., Henseler, J., \& Hair, J. F. (2014). On the Emancipation of PLS-SEM: A Commentary on Rigdon (2012). Long Range Planning, 47(3), 154-160. doi:10.1016/j.lrp.2014.02.007

Schmidt, J., Drews, P., \& Schirmer, I. (2018). Charting the emerging financial services ecosystem of fintechs and banks: Six types of data-driven business models in the fintech sector. Academic Press.

Shi, H., Wang, S., \& Zhao, D. (2017). Exploring urban resident's vehicular PM2.5 reduction behavior intention: An application of the extended theory of planned behavior. Journal of Cleaner Production, 147, 603-613. doi:10.1016/j.jclepro.2017.01.108

Shiau, W.-L., Sarstedt, M., \& Hair, J. F. (2019). Internet research using partial least squares structural equation modeling (PLS-SEM). Internet Research, 29(3), 398-406. doi:10.1108/IntR-10-2018-0447

Siddik, M. A. B., \& Rahi, S. T. (2020). Cybercrime in Social Media and Analysis of Existing Legal Framework: Bangladesh in Context. Bildbangladesh, 68.

Sikdar, P., \& Makkad, M. (2015). Online banking adoption. International Journal of Bank Marketing, 33(6), 760-785. doi:10.1108/IJBM-11-2014-0161

Singh, J., \& Sirdeshmukh, D. (2000). Agency and Trust Mechanisms in Consumer Satisfaction and Loyalty Judgments. Journal of the Academy of Marketing Science, 28(1), 150-167. doi:10.1177/0092070300281014

Singh, N., \& Sinha, N. (2020). How perceived trust mediates merchant's intention to use a mobile wallet technology. Journal of Retailing and Consumer Services, 52, 101894. doi:10.1016/j.jretconser.2019.101894

Stern, C., Makinen, M., \& Qian, Z. (2017). FinTechs in China-with a special focus on peer to peer lending. Journal of Chinese Economic and Foreign Trade Studies. 10.1108/JCEFTS-06-2017-0015

Sudiatmika, I. M. A., \& Purwanti, P. A. P. (2020). The Effect Of Fintech Transactions, E-Commerce, And Human Resources Quality On The Competitiveness Of Small Medium Apparel Industries In Denpasar City. Academic Press.

Surendran, P. (2012). Technology acceptance model: A survey of literature. International Journal of Business and Social Research, 2(4), 175-178. 
Szajna, B. (1996). Empirical evaluation of the revised technology acceptance model. Management Science, 42(1), 85-92. doi:10.1287/mnsc.42.1.85

Ullah, M. S. (2020). ICTs, power prejudice and empowerment: Digital exclusion of the poor in rural Bangladesh. In Digital inequalities in the global south. Springer.

Venkatesh, V., \& Davis, F. D. (2000). A theoretical extension of the technology acceptance model: Four longitudinal field studies. Management Science, 46(2), 186-204. doi:10.1287/mnsc.46.2.186.11926

Viswanathan, R. (2014). RBI report on financial inclusion: A review. Economic and Political Weekly, 16-19.

WHO. (2020). Enhancing Digital Government and Economy Project. WHO.

Wu, J.-H., \& Wang, S.-C. (2005). What drives mobile commerce?: An empirical evaluation of the revised technology acceptance model. Information \& Management, 42(5), 719-729. doi:10.1016/j.im.2004.07.001

Yin, H., \& Gai, K. (2015). An empirical study on preprocessing high-dimensional class-imbalanced data for classification. Paper presented at the 2015 IEEE 17th International Conference on High Performance Computing and Communications, 2015 IEEE 7th International Symposium on Cyberspace Safety and Security, and 2015 IEEE 12th International Conference on Embedded Software and Systems. doi:10.1109/HPCC-CSS-ICESS.2015.205

Yiu, C. S., Grant, K., \& Edgar, D. (2007). Factors affecting the adoption of Internet Banking in Hong KongImplications for the banking sector. International Journal of Information Management, 27(5), 336-351. doi:10.1016/j.jinfomgt.2007.03.002

Zaman, H. (2015). Service delivery process innovation: Insights from Digital Bangladesh. Innovation and Development, 5(1), 165-168. doi:10.1080/2157930X.2015.1009698

Prof. Fairtown Zhou Ayoungma is a Professor at Zhengzhou University, China and supervises PhD international students. His research interests are focused on social entrepreneurship.

Nazmul Hasan Chowdhury is a PhD candidate at Zhengzhou University in Public Economic Management since 2019. His research interests are in Social Entrepreneurship and FinTech Activities in Bangladesh.

Nida Hussain is a PhD candidate at Zhengzhou University, China in Public Economic Management since 2019. She obtained her BS in 2014 in Telecommunication Engineering from BUITEMS, Pakistan and MSc in 2018 degrees in Engineering Management from ICT, Pakistan. Her research interests include green technologies, green entrepreneurship, women social entrepreneurship, technology management and financial technologies.

Papel Tanchanga is a PhD candidate at Zhengzhou University in Industrial Economics since 2019. His research interests are in Social Entrepreneurship, FinTech and BRAC Activities in Bangladesh. 